\title{
Study of health and safety in the manufacturing industry using Pareto analysis
}

\author{
Petru Iulian Mureșan ${ }^{1, *}$, Ioan Miloșan ${ }^{1}$, Dorin Senchetru ${ }^{2}$, Adrian Nicolae Reit ${ }^{2}$, Teodor \\ Pisu Machedon ${ }^{1}$, and Gheorghe Oancea ${ }^{1}$ \\ ${ }^{1}$ Transilvania University of Brasov, 29 Eroilor Bld., 500036, Brasov, Romania \\ ${ }^{2}$ Territorial Labor Inspectorate of Brasov County, 17 Ioan Ratiu Str., 500080, Brasov, Romania
}

\begin{abstract}
The present paper carries out a study on health and safety in the manufacturing industry. The health and safety is analyzed for industrial workers in Brasov county for the years 2017 and 2018. The analysis is based on data for work related accidents and the processing was made using the Pareto Analysis. By complying with the $80 / 20$ rule, it can be focused on the analysis of the $20 \%$ of the causes of work accidents that account for $80 \%$ of the total work accidents analyzed. Finally, it is presented which actions that can be taken to reduce accidents based on the analysis of the specific stages. After applying the Pareto Analysis in the year 2018 are obtained satisfactory results compared to the year 2017, thus optimizing the performance of the industrial activity in terms of health and safety and improve Quality Assurance in Industrial Manufacturing.
\end{abstract}

\section{Introduction}

The statistics of the European Union, with all the inadequacies of incomplete data, showed that during a year of the previous decade, out of 120 million people in the 15 Member States about 5 million suffered an accident at work which led to temporary work incapacity longer than 3 days. Annually, in these countries, about 6,000 work accidents result in the death of the worker [1-6]. Every accident means physical and mental suffering, loss of income, time, etc. for those involved - victims, family, friends, but also an interruption of the activity imposed by the obligation to investigate the event and finding alternative solutions to continue the activity of the company.

Worldwide, investigations carried out by the International Labor Office indicate a direct cost of accidents and occupational illness of about $1 \%$ of the gross national product, while the total losses due to these events amount to $2-4 \%$ of the gross national product in the developed countries [1, 7-10].

\footnotetext{
* Corresponding author: petru.muresan@unitbv.ro
} 
Everyone wants security at the lowest cost. A particularly useful tool in achieving this goal is precisely the optimization of the management of occupational health and safety by taking into account the economic aspects of the efficient organization of occupational health and safety activity at micro and macroeconomic level.

Time is a determining factor in calculating the efficiency of how workforce is used. Periodical trainings of workers involve the fragmentation of the working schedule, with a direct impact on work-related activities of the trainee. In order for the training time to be a subsequent economic gain, it is necessary that the training be an efficient one and ensure, as a result of the training, an ongoing activity, without interruption caused by the lack of knowledge of the working procedures or the injury of the participants in the work process.

In this respect, a proposed alternative which could preferably also be implemented at the legislative level is the digitalization of the entire activity related to occupational health and safety, focusing on the online training and testing of the knowledge assimilated by the worker.

Developing a digital platform to ensure the optimization through digitalization of occupational safety and health work is also in line with the current requirements of the EU eGovernment Action Plan 2016-2020 - Accelerating the Digital Transformation of Governance, as set out in Communication 179 of 2016 To the European Parliament, the Council, the European Economic and Social Committee and the Committee of the Regions, which states that "eGovernment supports administrative processes, improves service quality and increases the internal efficiency of the public sector. Digital public services reduce the administrative burden for businesses and citizens, making their interactions with public administrations not only faster and more efficient, more practical and more transparent but also less expensive. Additionally, integrating the use of digital technologies into modernization strategies for administrations can provide "additional economic and social benefits for society as a whole" [11].

Work accidents, according to the statistics and the case study presented below, are largely due to the non-training of the contractor, which necessarily leads to the need to optimize and streamline the training process of the worker in all phases. Obviously, the efficiency of the worker's training is a component of the optimization process for the employer's overall activity, with direct consequences both in terms of protecting the health of the worker as well as in terms of productivity and quality of the production process.

\section{Case study developed for industrial companies from Brasov county}

The Pareto analysis is named after the engineer, sociologist, philosopher and economist Vilfredo Federico Damaso Pareto, who has formulated the $80 / 20$ principle of unbalanced distributions that postulates that $80 \%$ of the effects are generated by $20 \%$ of the causes [1214].

By carrying out the research with the Pareto analysis, there is performed a rigorous and pragmatic activity, very effective for multiple activities. With this analysis, the main categories of causes are identified; the contribution of each of them to the analyzed problem is identified, thus specifying the area in which the effort for optimizing the results should be focused. The Pareto chart is used in this study because there are measurable parameters, having records of each occurrence of parameters (the number of work accidents in Brasov County between 2017 and 2018). In Table 1 are listed the causes and number of workrelated accidents caused by contractors for 2017 . 
Table 1. Causes and number of work accidents caused by contractors in Brasov for the years 2017-2018

\begin{tabular}{|c|c|c|c|}
\hline \multirow[t]{2}{*}{ No. } & \multirow[t]{2}{*}{ Cause of the accident } & \multicolumn{2}{|c|}{$\begin{array}{l}\text { Number of } \\
\text { accidents/ } \\
\text { Year }\end{array}$} \\
\hline & & 2017 & $\begin{array}{l}20 \\
18\end{array}$ \\
\hline 1 & Inappropriate performance of orders, maneuvers & 91 & 86 \\
\hline 2 & Same-level falls (loss of balance, slipping, tripping, locking in & 55 & 57 \\
\hline 3 & $\begin{array}{l}\text { High-level falls (falling down, loss of balance, slipping, locking in, } \\
\text { spontaneous reactions inappropriate in case of danger) }\end{array}$ & 31 & 27 \\
\hline 4 & Failure to use protective equipment & 12 & 20 \\
\hline 5 & $\begin{array}{l}\text { Failure to observe in good time the operations indispensable to } \\
\text { occupational safety }\end{array}$ & 29 & 19 \\
\hline 6 & Inappropriate placement, consolidation, fixation & 21 & 19 \\
\hline 7 & Exposure besides work tasks by moving / staying in hazardous areas & 6 & 12 \\
\hline 8 & Presence at work with abrupt annihilation of functional ability & 2 & 5 \\
\hline 9 & Inappropriately performing assembly & 1 & 2 \\
\hline 10 & Inappropriate use of protective equipment & 2 & 2 \\
\hline 11 & $\begin{array}{l}\text { Performing operations other than the work duties such as turning on } \\
\text { transportation means, installations, machinery, gears }\end{array}$ & 4 & 1 \\
\hline 12 & Accidental communications through their content & 3 & 1 \\
\hline 13 & Presence at work under the influence of emotional states & 1 & 1 \\
\hline 14 & Presence at work in inappropriate conditions due to other causes & 2 & 1 \\
\hline & TOTAL & 260 & $\begin{array}{c}25 \\
3\end{array}$ \\
\hline
\end{tabular}

In order to analyze the data presented in Table 1 with the Pareto chart, the following steps will be performed:

1. Collecting data on the most common problems or errors occurring during specific activities;

2. Determining the frequency of repetition of the data analyzed during specific activities;

3. Determining the percentage share of each problem;

4. Determining the cumulative percentage of each problem;

5. Creating the Pareto chart;

6. Analyzing charts and proposing improvement measures.

Table 2 presents the data specific to the Pareto analysis on the causes and number of work accidents caused by contractors in Brasov County, for the year 2017.

Table 2. Processing the data specific to the Pareto analysis for the year 2017

\begin{tabular}{|c|c|c|c|c|c|c|}
\hline \multirow[b]{2}{*}{ No. } & \multirow[t]{2}{*}{ Causes of Workplace Accidents } & \multicolumn{2}{|c|}{ Frequency } & \multicolumn{2}{|c|}{ Percentage [\%] } & \multirow[t]{2}{*}{ Position } \\
\hline & & $\begin{array}{c}\text { absolute } \\
\left(\mathbf{f}_{\mathbf{a}}\right)\end{array}$ & $\begin{array}{l}\text { cumulative } \\
\text { absolute }\left(f_{\mathrm{ca}}\right)\end{array}$ & $\begin{array}{c}\text { Absolute } \\
\left(p_{a}\right)\end{array}$ & \begin{tabular}{|c|} 
cumulative \\
absolute $\left(p_{\mathrm{ca}}\right)$
\end{tabular} & \\
\hline 1 & $\begin{array}{l}\text { Inappropriate performance of } \\
\text { orders, maneuvers }\end{array}$ & 91 & 91 & $35,0 \%$ & $35,0 \%$ & I \\
\hline 2 & $\begin{array}{l}\text { Same-level falls (loss of balance, } \\
\text { slipping, tripping, locking in }\end{array}$ & 55 & 146 & $21,2 \%$ & $56,2 \%$ & II \\
\hline 3 & $\begin{array}{l}\text { High-level falls (falling down, } \\
\text { loss of balance, slipping, locking } \\
\text { in, spontaneous reactions } \\
\text { inappropriate in case of danger) }\end{array}$ & 31 & 177 & $11,9 \%$ & $68,1 \%$ & III \\
\hline 4 & $\begin{array}{l}\text { Failure to observe in good time } \\
\text { the operations indispensable to } \\
\text { occupational safety }\end{array}$ & 29 & 206 & $11,2 \%$ & $79,2 \%$ & IV \\
\hline
\end{tabular}




\begin{tabular}{|c|c|c|c|c|c|c|}
\hline \multirow[b]{2}{*}{ No. } & \multirow[t]{2}{*}{ Causes of Workplace Accidents } & \multicolumn{2}{|c|}{ Frequency } & \multicolumn{2}{|c|}{ Percentage [\%] } & \multirow[t]{2}{*}{ Position } \\
\hline & & $\begin{array}{c}\text { absolute } \\
\left(\mathbf{f}_{\mathrm{a}}\right)\end{array}$ & $\begin{array}{l}\text { cumulative } \\
\text { absolute }\left(\mathrm{f}_{\mathrm{ca}}\right)\end{array}$ & $\begin{array}{c}\text { Absolute } \\
\left(p_{a}\right)\end{array}$ & $\begin{array}{l}\text { cumulative } \\
\text { absolute }\left(p_{\text {ca }}\right)\end{array}$ & \\
\hline 5 & 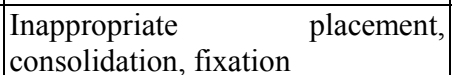 & 21 & 227 & $8,1 \%$ & $87,3 \%$ & V \\
\hline 6 & $\begin{array}{l}\text { Failure to use the provided } \\
\text { protective equipment }\end{array}$ & 12 & 239 & $4,6 \%$ & $91,9 \%$ & VI \\
\hline 7 & $\begin{array}{l}\text { Exposure besides work tasks by } \\
\text { moving / staying in hazardous } \\
\text { areas }\end{array}$ & 6 & 245 & $2,3 \%$ & $94,2 \%$ & VII \\
\hline 8 & $\begin{array}{l}\text { Performing operations other than } \\
\text { the work duties such as turning on } \\
\text { transportation means, installations, } \\
\text { machinery, gears }\end{array}$ & 4 & 249 & $1,5 \%$ & $95,8 \%$ & VIII \\
\hline 9 & $\begin{array}{l}\text { Accidentogenous communica- } \\
\text { tions through their content }\end{array}$ & 3 & 252 & $1,2 \%$ & $96,9 \%$ & IX \\
\hline 10 & $\begin{array}{l}\text { Presence at work with abrupt } \\
\text { annihilation of functional ability }\end{array}$ & 2 & 254 & $0,8 \%$ & $97,7 \%$ & $\mathrm{X}$ \\
\hline 11 & $\begin{array}{l}\text { Inappropriate use of protective } \\
\text { equipment }\end{array}$ & 2 & 256 & $0,8 \%$ & $98,5 \%$ & XI \\
\hline 12 & $\begin{array}{l}\text { Presence at work in inappropriate } \\
\text { conditions due to other causes }\end{array}$ & 2 & 258 & $0,8 \%$ & $99,2 \%$ & XII \\
\hline 13 & $\begin{array}{ll}\text { Inappropriately performing } \\
\text { assembly }\end{array}$ & 1 & 259 & $0,4 \%$ & $99,6 \%$ & XIII \\
\hline 14 & $\begin{array}{l}\text { Presence at work under the } \\
\text { influence of emotional states }\end{array}$ & 1 & 260 & $0,4 \%$ & $100,0 \%$ & XIV \\
\hline
\end{tabular}

Table 3 presents the data specific to the Pareto analysis regarding the causes and number of work accidents caused by contractors in Brasov County for the year 2018.

Table 3. Processing the data specific to the Pareto analysis for the year 2018

\begin{tabular}{|c|c|c|c|c|c|c|}
\hline \multirow[b]{2}{*}{ No. } & \multirow[t]{2}{*}{ Causes of Workplace Accidents } & \multicolumn{2}{|c|}{ Frequency } & \multicolumn{2}{|c|}{ Percentage $[\%]$} & \multirow[t]{2}{*}{ Position } \\
\hline & & $\begin{array}{c}\text { absolute } \\
\left(\mathbf{f}_{\mathrm{a}}\right)\end{array}$ & $\begin{array}{c}\text { cumulative } \\
\text { absolute }\left(f_{\text {ca }}\right)\end{array}$ & $\begin{array}{c}\text { Absolute } \\
\left(\mathbf{p}_{\mathrm{a}}\right)\end{array}$ & \begin{tabular}{|c} 
cumulative \\
absolute $\left(p_{\text {ca }}\right)$
\end{tabular} & \\
\hline 1 & $\begin{array}{l}\text { Inappropriate performance of } \\
\text { orders, maneuvers }\end{array}$ & 86 & 86 & $33,99 \%$ & $33,99 \%$ & I \\
\hline 2 & $\begin{array}{l}\text { Same-level falls (loss of balance, } \\
\text { slipping, tripping, locking in }\end{array}$ & 57 & 143 & $22,53 \%$ & $56,52 \%$ & II \\
\hline 3 & $\begin{array}{l}\text { High-level falls (falling down, } \\
\text { loss of balance, slipping, locking } \\
\text { in, spontaneous reactions } \\
\text { inappropriate in case of danger) }\end{array}$ & 27 & 170 & $10,67 \%$ & $67,19 \%$ & III \\
\hline 4 & $\begin{array}{l}\text { Failure to use the provided } \\
\text { protective equipment }\end{array}$ & 20 & 228 & $7,91 \%$ & $75,10 \%$ & IV \\
\hline 5 & $\begin{array}{l}\text { Failure to observe in good time } \\
\text { the operations indispensable to } \\
\text { occupational safety }\end{array}$ & 19 & 189 & $7,51 \%$ & $82,61 \%$ & $\mathrm{~V}$ \\
\hline 6 & $\begin{array}{l}\text { Inappropriate placement, } \\
\text { consolidation, fixation }\end{array}$ & 19 & 208 & $7,51 \%$ & $90,12 \%$ & VI \\
\hline 7 & $\begin{array}{l}\text { Exposure besides work tasks by } \\
\text { moving / staying in hazardous } \\
\text { areas }\end{array}$ & 12 & 240 & $4,74 \%$ & $94,86 \%$ & VII \\
\hline 8 & $\begin{array}{l}\text { Presence at work with sudden } \\
\text { annihilation of functional ability }\end{array}$ & 5 & 247 & $1,98 \%$ & $96,84 \%$ & VIII \\
\hline
\end{tabular}




\begin{tabular}{|c|c|c|c|c|c|c|}
\hline \multirow[b]{2}{*}{ No. } & \multirow[t]{2}{*}{ Causes of Workplace Accidents } & \multicolumn{2}{|c|}{\begin{tabular}{|c|} 
Frequency \\
\end{tabular}} & \multicolumn{2}{|c|}{ Percentage [\%] } & \multirow[t]{2}{*}{ Position } \\
\hline & & $\begin{array}{c}\text { absolute } \\
\left(\mathbf{f}_{\mathbf{a}}\right)\end{array}$ & $\begin{array}{l}\text { cumulative } \\
\text { absolute }\left(f_{\text {ca }}\right)\end{array}$ & $\begin{array}{c}\text { Absolute } \\
\left(p_{a}\right)\end{array}$ & \begin{tabular}{|c|} 
cumulative \\
absolute $\left(p_{\text {ca }}\right)$
\end{tabular} & \\
\hline 9 & $\begin{array}{l}\text { Inappropriate use of protective } \\
\text { equipment }\end{array}$ & 2 & 249 & $0,79 \%$ & $97,63 \%$ & IX \\
\hline 10 & $\begin{array}{|ll|}\begin{array}{l}\text { Inappropriately } \\
\text { assembly }\end{array} & \text { performing } \\
\end{array}$ & 2 & 252 & $0,79 \%$ & $98,42 \%$ & $\mathrm{X}$ \\
\hline 11 & $\begin{array}{l}\text { Performing operations other than } \\
\text { the work duties such as turning on } \\
\text { transportation means, } \\
\text { installations, machinery, gears }\end{array}$ & 1 & 241 & $0,40 \%$ & $98,81 \%$ & XI \\
\hline 12 & $\begin{array}{l}\text { Accidentogenous communications } \\
\text { through their content }\end{array}$ & 1 & 242 & $0,40 \%$ & $99,21 \%$ & XII \\
\hline 13 & $\begin{array}{l}\text { Presence at work in inappropriate } \\
\text { conditions due to other causes }\end{array}$ & 1 & 250 & $0,40 \%$ & $99,60 \%$ & XIII \\
\hline 14 & $\begin{array}{l}\text { Presence at work under the } \\
\text { influence of emotional states }\end{array}$ & 1 & 253 & $0,40 \%$ & $100,00 \%$ & XIV \\
\hline
\end{tabular}

Analyzing the data presented in tables 2 and 3, the following findings are made:

- the causes of workplace accidents (1-3) with the most injuries remain in the same positions;

- there are some changes in the positions of 2017 compared to 2018:

- $\quad$ position 4 (2017) becomes position 5 (2018);

- $\quad$ position 5 (2017) becomes position 6 (2018);

- $\quad$ position $6(2017)$ becomes position 4 (2018);

- $\quad$ position 8 (2017) becomes position 9 (2018);

- $\quad$ position 9 (2017) becomes position $12(2018)$;

- $\quad$ position 10 (2017) becomes position 8 (2018);

- $\quad$ position 11 (2017) becomes position 9 (2018);

- $\quad$ position 12 (2017) becomes position 3 (2018);

- there are positions that remain in place both years:

- $\quad$ position 7 (2017) remains on position 7 (2018);

- $\quad$ position 14 (2017) remains on position 14 (2018);

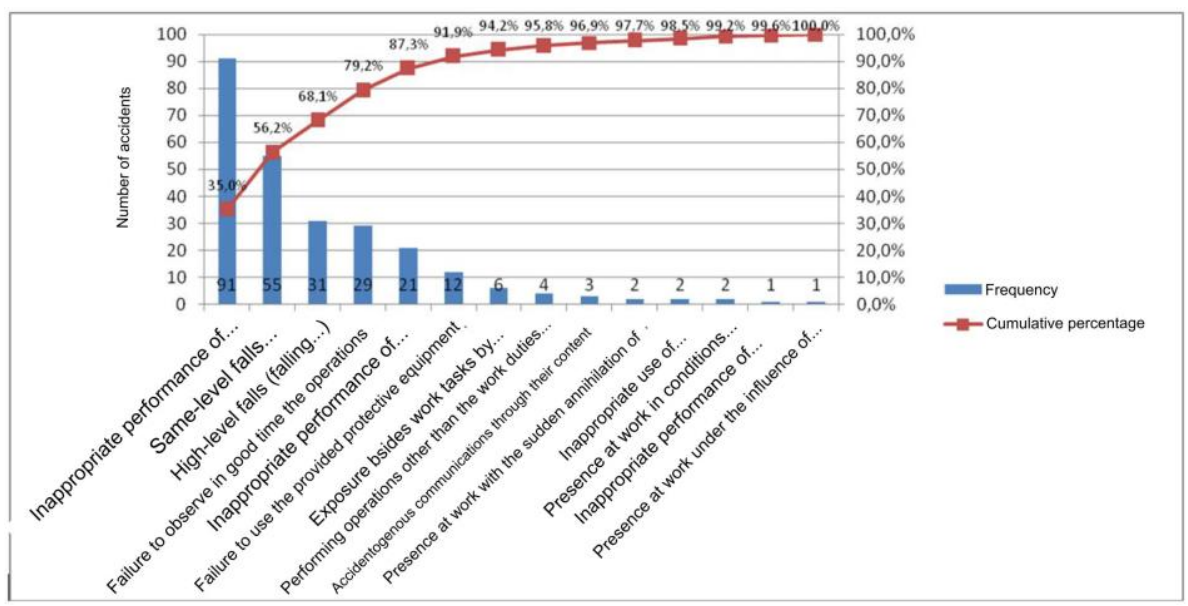

Fig. 1. The Pareto chart illustrates the causes and number of work accidents caused by the contractors in Brasov County, corresponding to 2017 


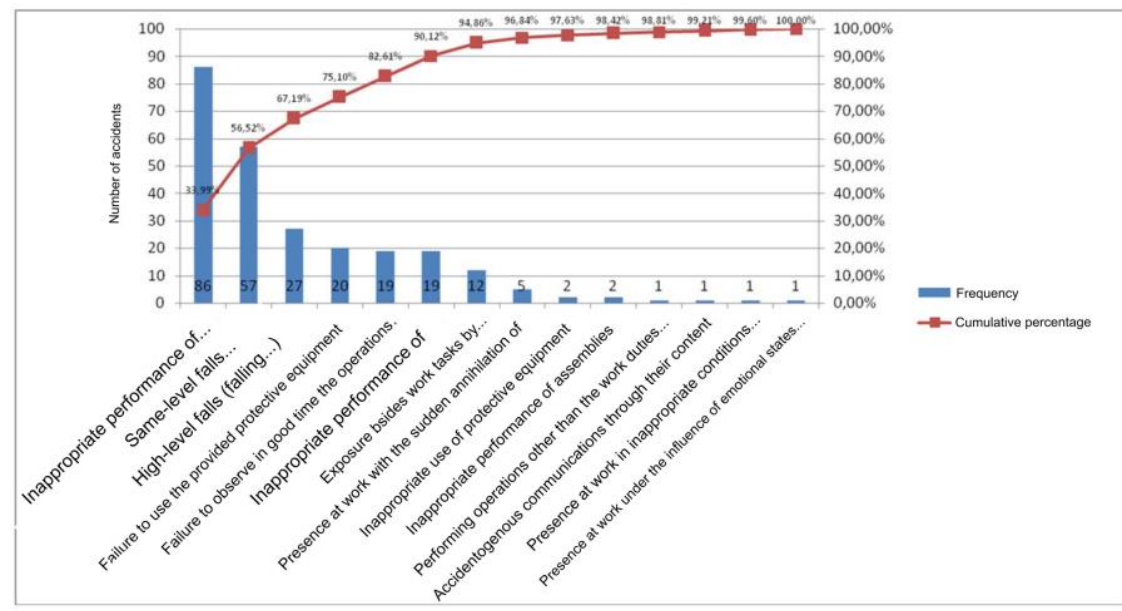

Fig. 2. The Pareto chart illustrates the causes and number of work accidents caused by the contractors in Brasov County, corresponding to 2018

Using the data presented in Table 2 and 3, the Pareto charts specific to 2017 and 2018 respectively are represented graphically in figures 1 and 2. Analyzing the data specific to the Pareto charts presented in Figures 1 and 2, it is noted that the cumulative share of work accidents in 2017 and 2018 goes up to almost $70 \%(68.1 \%$ in 2017 and $67.19 \%$ in 2018 ).

Table 4 contains the situation of the changes in the order of work accidents in 2017 compared to the ones in 2018

Table 4. The situation of the changes in the order of work accidents in 2017 compared to the ones in 2018

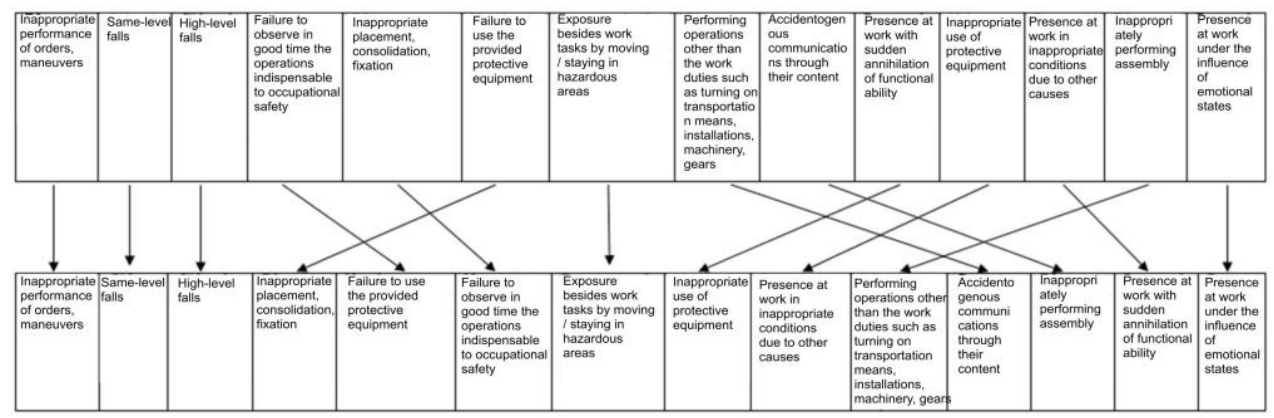

Analyzing the data presented in Table 4, the following findings are made:

- the number of work accidents decreased: from 260 (in 2017) to 253 (in 2018);

- the length of the arrows for the changes in the order of labor accidents in 2017 compared to 2018 is lower;

- the number of crosses specific to the changes in the share of work accidents in 2017 compared to 2018 is lower;

- fewer changes will result in the share of work accidents in 2017 compared to 2018. 


\section{Main directions to decrease work accidents}

The decrease in the number of work accidents in 2018 (252 work-related accidents) compared to 2017 (260 work accidents) could be also be achieved by using the facilities provided by the employee's online training platform. In the context of the above mentioned aspects, regarding the efficiency of the employer's activity in terms of obtaining superior results, both economically and in terms of maintaining, motivating and developing the professional abilities of the workers, I appreciate that the following facilities, brought by a digital platform for the complete management of occupational health and safety, highlights the need to use it:

a) lowering the costs of worker training by eliminating travel expenses and their costs related to the time spent by both the person compelled by law to carry out training and the worker who will interrupt the production process in order to attend the training;

b) streamlining the worker's training process by introducing compulsory testing of knowledge acquired during the training through electronic records that can be effectively managed. The elimination of formal situations involving only signing the training record without actually going through the training material is likely to increase the likelihood of a work accident, a situation which, in addition to the consequences of the damage to the health of the worker or the loss of his / her life is directly reflected in economic consequences for the employer. These consequences are directly and immediately reflected by: increasing the employer's contribution to the fund for accidents and illnesses risk; stopping production processes until the injured worker is replaced, with the direct consequence of failure to observe the deadlines committed to business partners, impacts on product quality or impossibility to engage in new contracts; negative results of audits that business partners ask for before entering into contracts or partnerships; developing the feeling of insecurity;

c) the opportunity the platform gives to any employee to communicate in real time any matter that may prevent him/her from working safely, and thereby removing initiatives to implement unsafe technical solutions that may lead to the occurrence of events that affect the worker's health or damage the work equipment used by the worker;

d) the opportunity that the platform provides for studying, the possibilities for the worker to understand and assimilate the information transmitted through the training for which he / she is being tested. It will then be possible to analyze the time required to go through the training material, the time it takes to respond correctly to the test questions that accompany each instruction, and the number of unsuccessful attempts to respond correctly. These elements are likely to generate conclusions or indications on the ability to acquire the knowledge required to carry out the safety activity by the trainee, but also on the possibility that the instruction may be unclear or too complex for the trainee's level of training. All these elements are meant to ensure the efficiency of the training process with the direct consequences shown in point $b$ );

e) making available to employers using this platform a simple and effective solution for monitoring the activity of isolated workers. Monitoring the isolated worker, with the help of the platform, aims to completely eliminate the costs associated with the salary of a worker whose main task is to supervise isolated workers. Also this technical solution is likely to lead to the rapid intervention of those able to provide first aid, or to verify the reasons why the isolated worker does not respond to the messages received from the platform during the established time and according to the procedure.

f) notifications and reports that the platform may generate, aim to inform the employer, at the time specified by the employer, of all time-bound obligations imposed by the legislation in force. Whether it is talking about the lack of general introductory training or the expiration of work training, the absence or expiration of periodical medical check-ups, 
the expiration of some permits or authorizations required to carry out a particular activity, the preparation and submission to the state authorities of documentation established by law etc.), both the failure to comply with legal obligations that may represent criminal and noncriminal deviations, and the consequences they may have on the worker's health.

\section{Conclusions}

Analyzing the data presented in the paper, the following conclusions can be drawn:

- Work accidents according to the statistics and case study presented above are largely caused by the contractor's lack of proper training, which necessarily leads to the need to optimize the worker training process in all phases. Therefore, making the worker training more effective will substantially and obviously help reduce the number of accidents which occur because of this cause;

- The Pareto chart is used in this study because there are measurable parameters, having records for each occurrence of parameters (the number of work accidents in Brasov County between 2017 and 2018).

- Causes of work accidents (1-3) with the most injuries remain on the same positions both in 2017 and in 2018;

- The decrease in the number of work accidents: from 260 (in 2017) to 253 (in 2018) can be amplified by using an on-line platform in the training process.

\section{References}

1. A. Dascalescu, Ed. Atlas, Bucharest, (2003)

2. N. Craciun, The Cost Assessment for Protection and Prevention of Activities Carried at Height, (2015)

3. F.H. Taufek, 7th Int. Ec. \& Business Management Conf., 705, (2016)

4. A. Targoutzidis, E. Koukoulaki, K. Schmitz-Felten, M. Kuhl, O. Karen, E. Hengel, K. Rijken, R. Van den Broek, R. Klüser, The business case for safety and health at work: (2014).

5. J. Verbeek, M. Pulliainen, E. Kankaanpää, Scand J Work Environ Health, 35 (6), 403 (2009)

6. S. Sullivan, J Occup Environ Med.,46(6 suppl), S56, (2004)

7. S. Lahiri, J. Gold, C. Levenstein, Am J Ind Med. 48(6), 530, (2005)

8. E. Kankaanpää, M. van Tulder, M. Aaltonen, M. De Greef, SJWEH Supplements 5, 9, (2008)

9. A. Burdorf, Scand J Work Environ Health., 33(3), 161, (2007)

10. P. Lanoie, S. Tavenas, Saf Sci., 24(3), 181, (1996)

11. E.U. COM/2016/0179 final (Brussels 19.4.2016).

12. T. Mahboob, B. Tariq, S. Anwar S., M. Khanum, Int. J of Comp. App., 121, 20 (2015)

13. F. Talib; Z. Rahman; M.N. Qureshi, International Journal for Quality Research, 4, 155 (2010)

14. Pareto Principle (80/20 Rule) \& Pareto Analysis,(2019). 